\author{
С. В. Бєгун ${ }^{1}$, С. В. Широков ${ }^{2}$ \\ ${ }^{1}$ Національний інститут стратегічних досліджень, \\ м. Київ, Україна \\ ${ }^{2}$ Національний технічний університет України \\ «Київський політехнічний інститут», м. Київ, Україна
}

\section{Реактори, що базуються на технології CANDU}

Проаналізовано використання реакторної технології CANDU у світовій атомній енергетиці. Розглянуто переваги й недоліки впровадження даної технології з економічної та технічної точки зору. Висвітлено технологічні проблеми використання реакторів типу CANDU, проблеми із забезпеченням ядерної безпеки. Визначено відповідні ризики впровадження даної реакторної технології в атомній енергетиці України.

Ключові слова: ядерний реактор, технологія CANDU, ядерна безпека, радіаційна безпека, економіка.

\section{С. В. Бегун, С. В. Широков}

\section{Реакторы, основанные на технологии CANDU}

Проведен анализ использования реакторной технологии CANDU. Рассмотрены преимущества и недостатки внедрения даной технологии с экономической и технической точки зрения. Освещены технологические проблемы использования реакторов типа CANDU, проблемы с обеспечением ядерной безопасности. Определены соответствующие риски внедрения данной технологии в атомной энергетике Украины.

Ключев ые слов а: ядерный реактор, технология CANDU, ядерная безопасность, радиационная безопасность, экономика.

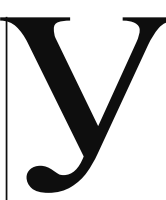

найрозвиненіших країнах світу внесок ядерної енергетики у виробництво первинної енергії, починаючи з часів створення перших ядерних енергетичних реакторів, стрімко зростав [1]: в середньому - у 6,4 раза (з 0,9\% у 1973 р. до $5,8 \%$ у 2008 р. [2]), а в країнах Організації економічного співробітництва та розвитку (ОЕСР) - у 8,7 раза (відповідно з 1,3 до $11,3 \%$ [2]). Настільки швидкий розвиток ядерної енергетики, на жаль, супроводжувався тяжкими аваріями на атомних електростанціях: на АЕС «Три-Майл-Айленд» (США) 28 березня 1979 р. [3], Чорнобильській АЕС (Україна) 26 квітня 1986 р. [4], АЕС «Фукусіма Даічі» (Японія) 11 березня 2011 р. [5]. Вплив цих аварій тою чи іншою мірою позначився на подальшому розвитку ядерної енергетики у світі. Наслідком кожної з цих аварій був грунтовний перегляд стандартів безпеки, що можна відслідкувати на офіційній інтернет-сторінці МАГАТЕ. Аварія на АЕС «Фукусіма Даічі» болюче вдарила по розвиткові ядерної енергетики у світі, 3 найбільшим впливом на країни Європи [6]. Тому зараз, як ніколи, необхідно дуже уважно підходити до питань ядерної та радіаційної безпеки, зокрема в процесі вибору реакторних технологій для будівництва нових енергогенеруючих потужностей в Україні. Підсилює важливість зваженого підходу до вибору реакторних технологій той факт, що саме в Україні сталася наймасштабніша у світі аварія на Чорнобильській AEC, та неоднозначне ставлення до ядерної енергетики, особливо в Україні [7]. Крім того, більшість нових проектів ядерних енергетичних реакторів розраховано на виробництво електроенергії впродовж 60 років, що додатково збільшує відповідальність прийняття рішення щодо вибору реакторної технології.

Ядерна енергетика, безумовно, є і залишиться у довгостроковій перспективі важливою складовою енергетичної безпеки України, чому сприяють наявна ресурсна база, розвинена інфраструктура та значний досвід експлуатації українських АЕС. Проте Україна, не володіючи власною реакторною технологією, має обирати з наявних на ринку реакторних технологій. Як один з варіантів, що пропонувався дослідити рішенням Ради національної безпеки і оборони України від 1 лютого 2008 р. «Про безпеку ядерної енергетики держави», затвердженим Указом Президента України № 156/2008 від 25 лютого 2008 р., $€$ реакторна технологія CANDU.

\section{Розробники промислових енергетичних ядерних реакторів на важкій воді}

І̇деї використання в ядерних реакторах важкої води як сповільнювача та природного урану як палива не є новими - вони з'явилися та розглядалися ще в середині минулого століття [8-10], але, зважаючи на певні проблеми та складнощі, не набули значного поширення у світі.

На сьогодні відомо кілька розробників промислових енергетичних ядерних реакторів на важкій воді. Насамперед, це канадська компанія Atomic Energy of Canada (далі - AECL), яка є розробником реакторів типу CANDU. За інформацією World Nuclear Association (WNA), починаючи з 1980-х років індійська компанія Nuclear Power Corporation of India Ltd (NPCIL), використовуючи за основу канадську технологію CANDU, розробляє ядерні реактори на важкій воді власного дизайну, які вже некоректно називати CANDU [11]. Фірма Siemens $є$ розробником одного з двох, що експлуатуються, та одного, що будується, 
ядерних реакторів на важкій воді в Республіці Аргентина. Відомі також розробки чехів в цьому напрямку, які не були доведені до впровадження у масове виробництво [12].

Останнім часом AECL майже зникла з ринку реакторних технологій [13] через об'єктивні чинники, головний серед яких - відсутність переважання попиту на ці реакторні установки на внутрішньому ринку Канади. Крім того, реактори на важкій воді мають значно менший досвід експлуатації порівняно з легководними реакторами з водою під тиском, що є стримуючим фактором на світовому ринку реакторних технологій. Так, на сьогодні у світі частка корпусних легководних реакторів з водою під тиском (саме такого типу реактори експлуатуються в Україні) становить $67 \%$ (за потужністю), в той час як реактори на важкій воді - лише 6,8 \% (типу CANDU - 5,7 \%, інші реактори на важкій воді - 1,1\%). Серед реакторів, що будуються, $-85 \%$ легководних корпусних з водою під тиском, 3,1 \% - на важкій воді i, зокрема, 0,0 \% реакторів на важкій воді типу CANDU [1].

Особливістю індійських розробок є орієнтація на внутрішній ринок, що обумовлено факторами, наведеними вище, та тривалою ізоляцією Їндії внаслідок неприєднання до Договору про нерозповсюдження ядерної зброї.

Таким чином, найбільш апробованою технологією ядерних реакторів на важкій воді $\epsilon$ технологія CANDU канадської фірми AECL, тому в подальшому розглядаються конструктивні особливості ядерних реакторів саме цієї компанії - CANDU-6, CANDU-9, EC-6 та ACR-1000. 3 них EC-6 та ACR-1000 є останніми розробками, що пропонуються на ринку ядерних технологій AECL.

\section{Переваги та недоліки реакторної технології CANDU}

Використання природного урану. Загальною перевагою реакторів на важкій воді є принципова можливість виробляти електроенергію, використовуючи як паливо природний (незбагачений) уран [10, 14], що дає змогу зменшити паливну складову в тарифі на вироблену електроенергію. Але в цьому випадку існують суттєві проблеми, які пов'язані з коефіцієнтами реактивності. До того ж, паливна складова у вартості електроенергії, виробленої на АЕС, за оцінками становить в середньому лише $15 \%$ [15]; 3 них тільки $6 \%$ припадає на послуги зі збагачення палива, $7 \%$ - це вартість природного урану, а $2 \%$ - вартість послуг з фабрикації ядерного палива. Тобто виграш від використання природного урану як палива не перевищуватиме $6 \%$ у вартості електроенергії, виробленої на АЕС. Відповідне зростання кількості відпрацьованого ядерного палива (ВЯП) у цьому разі може звести нанівець цей невеликий виграш, оскільки відрахування на поводження з ВЯП та з радіоактивними відходами становлять в середньому 5-10 \% вартості виробленої електроенергії.

Для порівняння: українські реактори типу ВBEР, що експлуатуються на даний час, потребують 250 т природного урану на 1000 МВт.років виробленої електроенергії [16], а реактори типу CANDU-6 та ЕC-6 - 180 т [17-20]. 1000 МВт.років (або 8,76.106 МВт.год) відповідає роботі енергоблока АЕС з встановленою потужністю 1000 МВт впродовж одного року з коефіцієнтом використання встановленої потужності $100 \%$ (для зручності порівняння). У реакторах типу CANDU всі 180 т природного урану після вивантаження з активної зони стають високоактивними радіоактивними відходами: вони містять залишки актиноїдів (U), напрацьовані в активній зоні актиноїди $(\mathrm{Pu}, \mathrm{Am}, \mathrm{Cm})$, продукти поділу актиноїдів та продукти їх активації. В реакторах типу ВВЕР із 250 т природного урану тільки 27 т завантажуються в ядерний реактор і після вивантаження з активної зони за рівнем радіоактивності відповідають високоактивним радіоактивним відходам; інші 223 т - це збіднений на ізотоп ${ }^{235} \mathrm{U}$ неопромінений в реакторі низькоактивний (природна радіоактивність) уран. Тому принципова можливість ядерних реакторів на важкій воді виробляти електроенергію, використовуючи як паливо природний (незбагачений) уран, не може бути визначальною у виборі даного типу реакторної установки.

Використання торію. Принципова можливість використовувати як паливо торій $\epsilon$ ще одною перевагою реакторів типу CANDU. Але розвиток ядерної енергетики з використанням торію у світі знаходиться тільки на початковій стадії, і значний досвід в цьому напрямку відсутній [11, $21,22]$. До того ж, технологія CANDU не є єдино можливою щодо використання торію як палива. Тому ця перевага не може бути визначальною у виборі даного типу реакторної установки на найближчу та середньострокову перспективу.

Використання відпрацьованого ядерного палива легководних реакторів. Можливість прямого використання ВЯП легководних реакторів з водою під тиском як палива для реакторів типу CANDU-6, CANDU-9 та EC-6 [10, 17-19, $23,24]$, або так званий DUPIC цикл, є наступною перевагою цих реакторних установок. DUPIC цикл неможливий для реакторів ACR-1000 [25], оскільки вони працюють на ядерному паливі із збагаченням $2,4 \%$ на ${ }^{235} \mathrm{U}$.

DUPIC цикл забезпечує додаткове виробництво електроенергії завдяки «допалюванню» ВяП, яке за відсутності замкненого ядерного паливного циклу мало би захоронюватися в глибоких геологічних формаціях чи відправлятися на переробку для виготовлення MOX-палива. В цьому разі не потрібно видобувати природний уран для завантаження у реактори CANDU-6, CANDU-9 та EC-6. Отже, для країн, де побудовані реактори типу CANDU та існує ВЯП від легководних ядерних реакторів, можна «економити» на природному урані, оскільки ВЯП легководних ядерних реакторів містить залишки актиноїдів та напрацьовані актиноїди, які мають порівнянні з величиною для ${ }^{235} \mathrm{U}$ перерізи поділу тепловими нейтронами [26] і принципово можуть бути використані для виробництва електроенергії.

ВЯП корейських легководних ядерних реакторів містить у середньому $1,0 \%{ }^{235} \mathrm{U}$ та $0,5 \%$ ізотопів $\mathrm{Pu}$. Вигоряння такого палива у DUPIC циклі в реакторах CANDU може сягати 13000 МВт.діб/т [27, 28]. Кількість ВЯП легководних ядерних реакторів, яку можна задіяти у DUPIC циклі в реакторах CANDU, за рік становить близько 100 т на 1000 МВт.років виробленої на реакторах CANDU електроенергії.

Але при використанні DUPIC циклу в реакторах CANDU існують, як і при використанні природного урану, суттєві проблеми, які пов'язані з коефіцієнтами реактивності. Крім того, додається проблема невизначеності складу ВЯП [28, 29], що призводить до відповідної невизначеності у прогнозуванні процесів у ядерному реакторі.

Необхідно чітко усвідомлювати, що випалювання актиноїдів до нульових концентрацій у реакторах CANDU при DUPIC циклі неможливе. Таке обмеження пов'язане, з одного боку, з низьким збагаченням палива та необхідністю забезпечення критичності ядерного реактора. 3 іншого 
боку, ядерний реактор, який працює на ${ }^{235} \mathrm{U}$, та ядерний реактор, який працює на ізотопах $\mathrm{Pu}$, мають суттєво різні експлуатаційні характеристики, що призводить до зміни експлуатаційних характеристик реакторів CANDU по мірі вигоряння ${ }^{235} \mathrm{U}$ у DUPIC паливі. Останнє додатково ускладнюється додатними коефіцієнтами реактивності, характерними для CANDU.

Наприкінці DUPIC циклу, на етапі вивантаження DUPIC палива з реакторів CANDU, по відношенню до початкового ізотопного складу DUPIC палива кількість ядер, що можуть ділитися під дією теплових нейтронів, зменшується на 53-54\%, кількість ${ }^{235} \mathrm{U}$ зменшується на $66 \div 69 \%$, кількість актиноїдів з урахуванням ${ }^{238} \mathrm{U}$ зменшується тільки на $1,6 \%$, загальна кількість урану зменшується тільки на $1,6 \%$, загальна кількість плутонію зменшується тільки на $2 \%$, кількість ${ }^{239} \mathrm{Pu}$ зменшується тільки на 34-35 \%, кількість ${ }^{241} \mathrm{Pu}$ зменшується тільки на 9,7 \%; при цьому на 33-43\% зростає кількість ${ }^{238} \mathrm{Pu}$ та на $30 \%$ зростає кількість продуктів поділу. Крім того, для зменшення невизначеності кількості ядер, які можуть ділитися тепловими нейтронами, застосовується варіант DUPIC циклу з використанням суміші слабкозбагаченого свіжого палива, збідненого урану з відвалів збагачувальних заводів та ВЯП легководних ядерних реакторів. У такому разі вміст ${ }^{241} \mathrm{Pu}$ у DUPIC паливі збільшується наприкінці паливної кампанії на 60 \% порівняно 3 вмістом при завантаженні в активну зону [28, 29]. Для забезпечення прийнятних експлуатаційних характеристик реакторів CANDU при використанні DUPIC циклу необхідно застосування диспрозієвих поглиначів з концентрацією в ядерному паливі до 5-6 \% [30].

Отже, випалювання ${ }^{235}$ U у DUPIC циклі дає змогу зменшити вимоги щодо критичності систем зберігання ВЯП, але слід звернути увагу на найбільш радіотоксичні радіонукліди плутонію, що майже не випалюються.

Світовий досвід проектування та використання сховищ ВЯП вказує на те, що розміри контейнерів для ВЯП значною мірою визначаються вимогами забезпечення саме тепловідведення [31]. Проаналізувавши енерговиділення ВЯП ядерних реакторів типу ВВЕР-1000, можна побачити, що у перші 50-60 років після його вивантаження з активної зони основний внесок у енерговиділення дають продукти поділу, а через 100 років $-{ }^{238} \mathrm{Pu}$ та ${ }^{241} \mathrm{Am}$, який утворився із ${ }^{241} \mathrm{Pu}$ вже після вивантаження з активної зони реактора [32].

При «допалюванні» ВЯП ядерних реакторів типу BBEP-1000 в реакторах CANDU кількість продуктів поділу в паливі буде додатково збільшуватися, про випалювання та напрацювання актиноїдів у DUPIC циклі йшлося вище. Енерговиділення відпрацьованого DUPIC палива буде більшим у перші 50-60 років, майже не відрізнятись у перші 10 тис. років і стане меншим лише через 2030 тис. років, ніж енерговиділення ВЯП ВВЕР-1000 без DUPIC циклу [10, 29, 32], тобто переваги відпрацьованого DUPIC палива з точки зору тепловиділення проявляться тільки через 20-30 тис. років після вивантаження 3 активної зони реактора.

Пряме використання цирконієвих оболонок палива легководних реакторів у збірках DUPIC палива небажане через значно вищу відносно свіжих цирконієвих оболонок ймовірність пошкодження [10]. Тому необхідно вилучити ядерне паливо з тепловидільних збірок, провести сортування за рівнем вигоряння та елементним складом $[10,28$, 29]. Для частини паливних таблеток ВЯП реактора типу
ВВЕР 3 діаметром 7-9 мм, а частини таблеток з центральним отвором [32], необхідно буде або створювати та ліцензувати спеціальні збірки DUPIC палива, або руйнувати паливні таблетки від ВВЕР та формувати їх відповідно до розмірів реактора ЕС-6 (13,08 мм) [10, 18, 28, 29], при цьому найімовірніше знадобиться додавання слабкозбагаченого свіжого палива та природного урану $[10,28,29]$.

На етапі вилучення та переробки ВЯП легководних реакторів з подальшою фабрикацією DUPIC палива виникають ризики опромінення персоналу та населення, оскільки проводиться робота з великою кількістю (сотні тонн щорічно) високоактивних відкритих джерел іонізуючого випромінювання. Відсутність значного досвіду в цьому напрямку, особливо в Україні, є суттєвим стримуючим фактором.

Використання DUPIC циклу не вирішує проблеми поводження з ВЯП та обмеженості ресурсів для ядерної енергетики 3 використанням ізотопу урану ${ }^{235} \mathrm{U}$, що обмежує можливості застосування подібного підходу найближчою перспективою через його неконкурентноздатність порівняно 3 використанням реакторів на швидких нейтронах у середньостроковій та віддаленій перспективі [33, 34]. Крім того, відрахування на поводження з ВЯП та радіоактивними відходами становлять в середньому лише 5-10\% вартості електроенергії, виробленої на АЕС [15]. До того ж, заходи, спрямовані на збільшення тривалості експлуатації ядерного палива в активній зоні понад три роки в проектах легководних ядерних реакторів, суттєво зменшують переваги DUPIC циклу з економічної точки зору (залишається менше палива, яке можна спалити). Тому можливість прямого використання ВЯП легководних реакторів як палива для реакторів типу CANDU не може бути визначальною у виборі реакторної установки типу CANDU.

Імовірність тяжкого пошкодження активної зони $A C R-1000$. Реакторній установці типу ACR-1000 властиве низьке значення ймовірності тяжкого пошкодження активної зони - порядку $10^{-7}$ на рік [25]. Але подібні ж показники має значно кращий за багатьма показниками проект «АЭС-2006» (ВВЭР-1200) російської компанії ОКБ «Гидропресс» [35]. До того ж, на реакторну установку ACR-1000 відсутній попит як на внутрішньому ринку Канади, так і на зовнішніх ринках [1, 13].

Коефіцієнт використання встановленої потужності. Для проектів реакторів типу CANDU характерним $є$ високе значення коефіцієнта використання встановленої потужності (близько $90 \%$ ) завдяки можливості перевантаження палива під час роботи реактора $[10,18,23,25]$. Але подібні ж показники за рахунок подовження періоду між перевантаженням палива має значно кращий за багатьма показниками проект «АЭС-2006» (ВВЭР-1200) російської компанії ОКБ «Гидропресс» [36].

Досвід експлуатації. Один з недоліків реакторів CANDU полягає в значно меншому (майже в десять разів) досвіді їх експлуатації порівняно з реакторами на легкій воді. На недостатність відпрацювання низки технологій в нових реакторах CANDU вказує і академік Національної академії наук України, завідувач відділу Інституту теоретичної фізики ім. О. І. Ахієзера ННЦ «Харківський фізико-технічний інститут» НАН України О. С. Бакай [37]. В Україні відсутній досвід створення та експлуатації реакторів на важкій воді.

Розміри. Для реактора типу CANDU потрібно будувати активну зону значну більшого розміру (у 2,2 раза), ніж розмір активної зони еквівалентного за потужністю 
корпусного легководного реактора з водою під тиском [14]. Цей недолік обумовлений об'єктивним, незалежним від конструкції активної зони фактором (тобто подібний ефект не можна усунути покращенням конструкції активної зони реактора) - гіршою здатністю важкої води сповільнювати нейтрони. Їснування цього недоліку призводить до складнощів управління CANDU та є стримуючим фактором у підвищенні потужності одиничної реакторної установки цього типу в наявних та майбутніх проектах. Саме цей ефект $є$ причиною відсутності проектів реакторів типу CANDU на важкій воді з потужністю по електроенергії, вищою за 1000 МВт [1]

Коефіцієнт реактивності. Одним з визначальних недоліків усіх проектів CANDU є додатний пустотний коефіцієнт реактивності, особливо при використанні природного (незбагаченого) урану [10, 18, 23, 25, 38-41]. Пустотний коефіцієнт реактивності визначається за формулою [30]

$$
\mathrm{c}_{v}=\left(\frac{1}{k_{e f}}-\frac{1}{k_{v}}\right),
$$

де $k_{e f}-$ ефективний коефіцієнт розмноження нейтронів за наявності теплоносія; $k_{v}$ - ефективний коефіцієнт розмноження нейтронів без теплоносія.

Розрахована за формулою (1) величина $\rho_{v}$ відповідає відносній зміні коефіцієнта розмноження нейтронів $(\Delta k / k)$.

Для реакторів типу CANDU найбільше значення $\rho_{v}=14 \cdot 10^{-3}[24,28]$ досягається в разі використання природного (незбагаченого) урану з тенденцією до зменшення при збагаченні урану на ізотоп урану ${ }^{235} \mathrm{U}$ та 3 наближенням до нуля й виходом у від'ємний діапазон при збагаченні ядерного палива на ізотоп ${ }^{235} \mathrm{U}$ понад $2,4-3 \%$ [42] (стосується проектів CANDU-6, CANDU-9 та EC-6). При використанні DUPIC циклу для CANDU-6 або EC-6 пустотний коефіцієнт реактивності залишається додатним, але меншим, ніж при використанні природного (незбагаченого) урану, і дорівнює $12 \cdot 10^{-3}[24,27,28]$. В аварійній ситуації, пов'язаній з CANDU-6 або ЕC-6, зі збільшенням об'єму пустоти внаслідок втрати теплоносія $\rho_{v}$ лінійно збільшуватиметься [27] від нуля до максимального значення [див. формулу (1)]. Для CANDU-6 або ЕC-6 $\rho_{v}=6,5 \cdot 10^{-3}$ у разі втрати $50 \%$ теплоносія при використанні DUPIC циклу і 7,4·10 - - у разі втрати $50 \%$ теплоносія при використанні природного (незбагаченого) урану [24].

Додатний пустотний коефіцієнт реактивності означає, що $з$ виникненням у теплоносії CANDU-6, CANDU-9 та EC-6 пустот через втрату теплоносія чи його кипіння, потужність реактора зростатиме із збільшенням об'єму пустот та поширенням кипіння в об'ємі ядерного реактора; зростання потужності призводитиме до подальшого підвищення температури, підвищення температури - до подальшого розвитку процесу кипіння, внаслідок чого можлива аварія з частковим пошкодженням чи, за малоймовірного збігу обставин, - 3 руйнуванням активної зони реактора. При від'ємному значенні пустотного коефіцієнта реактивності поява пустот або кипіння призводили би до зменшення потужності реактора та, відповідно, до його зупинки чи припинення кипіння, що, на жаль, не властиво реакторам типу CANDU. Спеціалісти AECL стверджують, що наявність двох незалежних швидкодіючих (йдеться про час спрацювання 2 с [40]) систем аварійного захисту реактора (стрижні-поглиначі нейтронів та рідина, що поглинає нейтрони) убезпечує його експлуатацію, але ж існує ймовірність відмови цих систем аварійного захисту.
Перед розглядом цієї відмови слід згадати, що в разі, коли абсолютна величина реактивності $\left(\rho_{y}\right)$ перевищує сумарну частку запізнюючих нейтронів у повній кількості нейтронів ділення ( $\beta)$, починається швидке (в десятки разів за кілька секунд) неконтрольоване збільшення потужності реакторної установки за рахунок миттєвих нейтронів [43]. Величина $\beta$ для ${ }^{235} \mathrm{U}$ дорівнює $6,4 \cdot 10^{-3}$, а для ${ }^{239} \mathrm{Pu}-2,1 \cdot 10^{-3}$ [43]. Наприкінці паливної кампанії кожної конкретної тепловидільної збірки по відношенню до iii початку внесок від поділу ядер плутонію в цій тепловидільній збірці значно (у 2,2-2,5 раза для DUPIC циклу) зростає [28, 43], що призводить до зміни експлуатаційних характеристик збірки у гірший з точки зору ядерної безпеки бік через зменшення параметра $\beta$. Саме тому усереднені по активній зоні параметри реактивності реакторів типу CANDU на початку паливної кампанії (при першому завантаженні чи після поточного ремонту) значно відрізняються від рівноважних (середина паливної кампанії) [28, 43]. Так, у середньому по активній зоні реактора, внесок поділу ядер плутонію зростає в рівновазі (середина паливної кампанії) відносно початку паливної кампанії реактора на 30-37 \% для ядерного палива у DUPIC циклі [28, 43], що призводить до збільшення додатних коефіцієнтів реактивності та погіршення з точки зору ядерної безпеки усереднених параметрів ядерного реактора. Реальне значення $\beta$ в рівновазі дорівнює $(5,1 \div 5,3) \cdot 10^{-3}$ для DUPIC циклу [28].

Додатково слід проаналізувати температурні коефіцієнти реактивності. Коефіцієнт реактивності за температурою палива в рівновазі становить від $-1,1 \cdot 10^{-6}$ до $-1,7 \cdot 10^{-6} \mathrm{~K}^{-1}$ для DUPIC циклу [28], що означає зменшення реактивності приблизно на $0,17 \cdot 10^{-3}$ при зростанні температури палива на 100 K. Тому, щоб ввести від'ємну реактивність хоча б на рівні $1 \cdot 10^{-3}$, температуру палива потрібно збільшити приблизно на $600 \mathrm{~K}$. Коефіцієнти реактивності за температурою сповільнювача та температурою теплоносія в рівновазі є додатними величинами $[28,40]$. Коефіцієнт реактивності за температурою теплоносія в рівновазі становить від $47 \cdot 10^{-6}$ до $50 \cdot 10^{-6} \mathrm{~K}^{-1}$ для DUPIC циклу [28], що означає збільшення реактивності приблизно на $0,5 \cdot 10^{-3}$ при зростанні температури теплоносія лише на $10 \mathrm{~K}$. Коефіцієнт реактивності за температурою сповільнювача в рівновазі становить від $4,5 \cdot 10^{-6}$ до $14 \cdot 10^{-6} \mathrm{~K}^{-1}$ для DUPIC циклу [28], що означає збільшення реактивності приблизно на $0,05 \cdot 10^{-3}$ при зростанні температури теплоносія лише на $10 \mathrm{~K}$.

Далі для CANDU-6 та ЕC-6 розглянемо ситуацію розриву однієї з гілок трубопроводу першого контуру в найбільшому перерізі - ситуацію, що входить до стандартного переліку аварійних ситуацій у процесі аналізу безпеки ядерних реакторів (зокрема, типу ВBEP). У випадку CANDU це призведе до утворення течі з витратою на рівні близько $50 \%$ загальної витрати теплоносія першого контуру з тенденцією до спадання величини потоку $[10,18]$. Розглянемо при цьому сценарій з одночасною відмовою спрацювання обох систем аварійного захисту та відмовою спрацювання системи підживлення першого контуру. В міру витікання теплоносія за рахунок додатного пустотного коефіцієнта реактивності збільшуватиметься реактивність відповідної реакторної установки типу CANDU на рівні $(1 \div 3) \cdot 10^{-3} 1 / \mathrm{c}$ [10], при цьому температура оболонки палива та самого палива збільшуватиметься на рівні 100-200 K/с до $1500 \mathrm{~K}$ приблизно з подальшим уповільненням [10]. Від'ємної реактивності за температурою палива буде недостатньо, щоб вивести реактор у підкритичний стан, оскільки нагрівання 
палива відбуватиметься повільніше, ніж збільшення реактивності за рахунок додатного пустотного коефіцієнта реактивності [10]. Крім того, ситуацію погіршують додатні коефіцієнти реактивності за температурами сповільнювача та теплоносія. Це означає, що в такій ситуації реактор типу CANDU вже не зупиниться до самого руйнування. Тому в фундаментальній роботі [10] навіть не розглядається можливість неспрацювання обох систем аварійного захисту: в подібній ситуації аварійний захист - єдина (безальтернативна) можливість уникнути тяжкої аварії [10]. Такий жахливий збіг обставин в принципі є малоймовірним, але не може бути проігнорованим зважаючи на значні наслідки.

На відміну від реакторів CANDU-6 та ЕC-6, більшість легководних реакторів з водою під тиском в ситуації з неспрацюванням аварійного захисту та значною втратою теплоносія за рахунок від'ємних коефіцієнтів реактивності стануть підкритичними.

Зауважимо, що саме додатне значення пустотного коефіцієнта реактивності розглядається як одна з головних причин аварії на Чорнобильській АЕС [44-46]; на реакторі РБМК-1000 цей коефіцієнт дорівнював $34 \cdot 10^{-3}$ [45]. Порівняймо з відповідними параметрами для реакторів типу CANDU $-12 \cdot 10^{-3}$ (DUPIC) та $14 \cdot 10^{-3}$ (природний уран) [24, 28].

Спробу вирішити проблему додатності пустотного коефіцієнта реактивності було зроблено в проекті реактора ACR-1000, але в більшості випадків коефіцієнт залишається додатним, хоча значно меншим (приблизно вп'ятеро), ніж у проектах CANDU-6, CANDU-9 та EC-6 [25, 38]. У деяких, але, на жаль, не в усіх, режимах експлуатації ACR-1000 цей коефіцієнт від'ємний. Досягти цього вдалося, головним чином, використовуючи в активній зоні ACR-1000 низькозбагачений уран на ізотоп ${ }^{235} \mathrm{U}$ (середне збагачення 2,4 \%). Для порівняння, природний (незбагачений) уран містить у середньому $0,72 \%$ ізотопу ${ }^{235} \mathrm{U}[26]$.

Кількість радіоактивних відходів. Можливість отримати певну кількість енергії з ядерного палива на основі урану в першу чергу визначається вмістом у цьому паливі ізотопу урану ${ }^{235} \mathrm{U}$ : чим більший вміст ${ }^{235} \mathrm{U}$ - тим більшу кількість енергії можна потенційно отримати з однакової маси урану. За грубою оцінкою (з точністю 35-40 \%) відношення кількості ВЯП у різних ядерних реакторах на теплових нейтронах можна прирівняти до відношення збагачення палива цих реакторів на ${ }^{235} \mathrm{U}$. Для легководних реакторів при вмісті ${ }^{235} \mathrm{U}$ на рівні 4-5 \% (ВВЕР-1000 - 4,4\% [32]), вміст ${ }^{235} \mathrm{U}$ приблизно у 6 разів більший, ніж у природномy (EC-6, CANDU-6 - 0,72\%) та у 1,8 раза більший, ніж у низькозбагаченому урані (ACR-1000-2,4\%). Отже, за грубою оцінкою на реакторах типу CANDU утворюватиметься у 1,8-6,1 раза більше радіоактивних відходів.

Другий спосіб оцінки співвідношення кількості радіоактивних відходів полягає в порівнянні величин сумарного вигоряння ядерного палива. Досяжне сумарне вигоряння ядерного палива реактора типу ВВЕР-1000, що експлуатуються в Україні, становить понад 40480 МВт.діб/т [32]. У реакторах CANDU-6 та ЕC-6 при використанні природного урану досяжне (згідно з документацією) сумарне вигоряння ядерного палива - 7500 МВт.діб/т [18], у реакторі ACR-1000 - 20000 МВт.діб/т [25]. Це означає, шо, за однакової кількості виробленої електроенергії та досяжних на цих реакторах параметрів вигоряння ядерного палива, на реакторах типу CANDU утворюватиметься в 2,0-5,4 раза більша кількість ВЯП.
Реальні цифри, наведені на початку статті, ще гірші. Відрахування на поводження з ВяП та радіоактивними відходами ядерних реакторів типу CANDU у вартості виробленої електроенергії мають зростати відносно середньої величини $(5-10 \%)$ в разі наведеного збільшення їх кількості, майже повністю перекриваючи виграш від відсутності послуг із збагачення.

Маневреність. Реактори CANDU-6, ЕC-6 при використанні природного урану чи DUPIC циклу працюють на межі (з невеликим запасом реактивності $k_{e f}<1,02$ ) [47]. Тому ці реактори обмежені щодо маневрування через порівнянний з запасом реактивності вплив ксенонових коливань [47]. Додатково обмежують можливості маневрування додатний пустотний коефіцієнт реактивності й додатні температурні коефіцієнти реактивності за температурами сповільнювача та теплоносія.

Водночас найкращі зразки реакторів III+ покоління «АЭС-2006» (ВВЭР-1200) [48] та EPR-1650 [49] забезпечують можливість маневрування на рівні $5 \%$ номінальної потужності за хвилину, що дає змогу повноцінно використовувати блоки AEC з такими реакторами в добовому регулюванні потужності енергосистеми України [50]. Тому, за умови використання реакторів типу AEC-2006 та EPR-1650, в Україні можливе збільшення частки AEC у загальному виробництві електроенергії понад $50 \%$.

Утворення тритію. Значну проблему з убезпечення довкілля та персоналу АЕC з реакторами типу CANDU становить утворення радіоактивного ізотопу водню - тритію $[51,52]$ внаслідок активації ізотопу водню дейтерію, який $€$ складовою молекули важкої води. Тритій на два-три порядки менш радіотоксичний, ніж ${ }^{131} \mathrm{I},{ }^{90} \mathrm{Sr}$ або ${ }^{137} \mathrm{Cs}$ [53], проте об'єми його щорічних викидів вимірюються сотнями текабеккерелей [51, 52].

При цьому слід констатувати відсутність в Україні досвіду переробки значної кількості (десятки або сотні тонн щорічно) високоактивних рідких радіоактивних відходів, що містять значну кількість тритію.

Потреба у важкій воді. Щорічні потреби у високоочищеній (вміст легкої води менший за 0,25\%) важкій воді становлять 60-80 т на 1000 МВт (ел.) встановленої потужності [54]. При цьому в Україні відсутні потужності, спроможні забезпечити достатню кількість високоочищеної важкої води.

Bapmicmb. За інформацією WNA, Румунія розглядає перспективу побудови в майбутньому двох енергоблоків 3 реакторами типу CANDU одиничною потужністю 720 МВт (ел.). Очікувана вартість побудови цих двох блоків - 5,6 млрд доларів США. Це означає, що питома вартість 1 кВт встановленої потужності дорівнюватиме 3889 доларам США, що на $11 \%$ більше питомої вартості спорудження EPR-1650 та на 57 \% більше наявних даних щодо питомої вартості спорудження «АЭС-2006» (ВВЭР-1200).

Поведінка в умовах тяжких аварій. Активні зони в реакторах типу CANDU спроектовані так, що середня питома потужність, яка виділяється в ядерному паливі, знаходиться на одному рівні (приблизно у 1,2 раза менша) 3 подібною величиною в корпусних реакторах на легкій воді з водою під тиском [18, 25, 32]. При цьому ймовірність тяжкого пошкодження активної зони в реакторах типу CANDU не нижча, ніж для інших реакторів $[18,25,35]$.

Дослідження можливих сценаріїв тяжких аварій на реакторах типу CANDU знаходяться на початковій стадії, 
а результати досліджень різних авторських колективів не узгоджуються щодо можливих наслідків. При цьому всі реактори типу CANDU (CANDU-6, CANDU-9, EC-6 та ACR-1000) не мають у своїй конструкції уловлювача розплаву палива. Вказані недоліки значно ускладнюють оцінку переваг реакторів типу CANDU порівняно з найкращими розробками корпусних ядерних реакторів на легкій воді з водою під тиском.

\section{Висновки}

У зв'язку з Чорнобильською катастрофою, 25-ті роковини якої відзначалися у 2011 р., та аварією на АЕС «Фукусіма Даічі» (Японія, 11 березня 2011 р.) нагальним питанням розвитку атомної енергетики є забезпечення ядерної та радіаційної безпеки, надійності реакторних технологій, що застосовуються на АЕС.

Ядерна енергетика $є$ і залишиться у довгостроковій перспективі важливою складовою енергетичної безпеки України. Проте Україна, не володіючи власною реакторною технологією, має обирати з наявних на ринку реакторних технологій. Як один з варіантів, що пропонувався дослідити рішенням Ради національної безпеки і оборони України від 1 лютого 2008 р. «Про безпеку ядерної енергетики держави», затвердженим Указом Президента України № 156/2008 від 25 лютого 2008 р., є реакторна технологія CANDU.

На сьогодні у світі частка корпусних легководних реакторів з водою під тиском (саме такого типу реактори експлуатуються в Україні) становить 67 \% (за потужністю), в той час як реактори на важкій воді - лише 6,8 \% (типу CANDU - 5,7 \%, інші реактори на важкій воді - 1,1\%). Серед реакторів, що будуються, $-85 \%$ легководних корпусних з водою під тиском, 3,1 \% - на важкій воді i, зокрема, $0,0 \%$ реакторів на важкій воді типу CANDU.

Аналіз переваг та недоліків реакторної технології CANDU доводить відсутність явних переваг цієї технології з економічної та технічної точки зору, наявність технологічних проблем їі впровадження. У порівнянні з іншими існуючими реакторними технологіями технологія CANDU характеризується більшою кількістю відпрацьованого ядерного палива, що утворюється на одиницю виробленої електроенергії. Крім того, дана технологія має низку проблем із забезпеченням ядерної безпеки.

\section{Список використаної літератури}

1. Power Reactor Information System // http://www.iaea.org/ programmes/a2.

2. Key World Energy Statistics. - OECD/IEA: International Energy Agency, 2010. - $82 \mathrm{p}$.

3. Report of the President Commission on the Accident at the Three Mile Island. The Need for Change: the Legacy of TMI. - Washington D.C.: The President's Commission on the Accident at TMI, 1979. $178 \mathrm{p}$.

4. INSAG-7. Чернобыльская авария: дополнение к INSAG-1. Доклад Международной консультативной группы по ядерной безопасности. - Вена: МАГАТЭ, 1993. - 158 с.

5. Report of the Japanese Government to the IAEA Ministerial Conference on Nuclear Safety - The Accident at TEPCO's Fukushima Nuclear Power Stations. - Nuclear Emergency Response Headquarters: Government of Japan, June 2011. - $823 \mathrm{p}$

6. Блинова И. В. Авария на АЭС «Фукусима-І» и ее влияние на развитие ядерной энергетики / И. В. линова, И. Д. Соколова //Атомная техника за рубежом. - 2011. - № 7. - С. 3-17.
7. Думка громадян України про ядерну енергетику. Результати соціологічного дослідження / Центр екон. і політ. досліджень ім. О. Разумкова. - 21 квітня 2011 р. - 7 с. - http://www. razumkov.org.ua

8. Петров П. А. Ядерные энергетические установки. - М.; Л.: Госэнергоиздат, 1958. - $256 \mathrm{c.}$

9. Левин В. Е. Ядерная физика и ядерные реакторы: Учеб. для техникумов. - Изд. 4-е, перераб. и доп. - М.: Атомиздат, 1979. $288 \mathrm{c}$.

10. Heavy Water Reactor: Status and Projected Development. Technical Report Series № 407. STI/DOC/010/407. - Vienna: IAEA, April 2002. - 703 p.

11. Sinha R. K. Design and development of the AHWR - the Indian thorium fuelled innovative nuclear reactor / Sinha R. K., Kakodkar A. // Nuclear Engineering and Design. - 2006. - Vol. 236. - P. 683-700.

12. Ашихмин В. П. Создание тепловыделяюших элементов для реактора КС-150 первой чехословацкой атомной станции А-1/ В. П. Ашихмин, В. В. Степина // Енергетика та електрифікація. - 2007. - № 9. - С. 55-59.

13. Преображенская Л. Б. Новые АЭС: успехи и проблемы. Ч. 1: Строяшиеся и планируемые к строительству ядерные енергоблоки / Л. Б. Преображенская, И. Д. Соколова //Атомная техника за рубежом. - 2011. -№ 5. - С. 3-15.

14. Широков С. В. Ядерні енергетичні реактори: Навч. посібник. - К.: НТУУ «КПІ», 1997. - 280 с.

15. Issues to improve the prospects of financing nuclear power plants. IAEA Nuclear Energy Series No. NG-T-4.1. - Vienna: IAEA, 2009. - $43 \mathrm{p}$.

16. Uranium 2009: Resources, Production and Demand. A Joint Report by the OECD Nuclear Energy Agency and the International Atomic Energy Agency. NEA No.6891. - OECD: Nuclear Energy Agency OECD, 2010. - $452 \mathrm{p}$.

17. Guang $Y$. The status quo of China's nuclear power and the uranium gap solution Guang Y., Wenji H. // Energy Policy. - 2010. Vol. 38. - P. 966-975.

18. Status report 68 - Enhanced CANDU 6 (EC6). Status Report for Advanced Nuclear Reactor Designs - Report 68. - Vienna: IAEA, 01.04.2011. - $42 \mathrm{p}$

19. Enhanced CANDU 6 Technical Summary. - Canada: AECL, November 2009. $-48 \mathrm{p}$.

20. CANDU 6 Technical Summary. - AECL: CANDU 6 Program Team, June 2005. $-62 \mathrm{p}$.

21. Тарнавский В. Ториевый шанс // Энергобизнес. - 27 апреля 2011 г. - № 17/703. - С. 22-25.

22. Глебов А. П. Тепловой реактор с уран-плутоний-ториевым топливным циклом, охлаждаемый водой сверхкритического давления при двухходовой схеме движения / А. П. Глебов, А. В. Клушин // Атомная энергия. - Май 2009. - Т. 106, вып. 5. - С. 243-249.

23. Improving economics and safety of water cooled reactors. Proven means and new approaches. IAEA-TECDOC-1290. - Vienna: IAEA, May 2002. - $298 \mathrm{p}$.

24. Yang M. S. The status and prospect of DUPIC fuel technology / Yang M. S., Choi H., Jeong C. J., et al. // Nuclear Engineering and Technology. - 2006. - Vol. 38, No. 4. - P. 359-374.

25. Status report 69 - Advanced Candu Reactor 1000 (ACR-1000). Status Report for Advanced Nuclear Reactor Designs - Report 69. Vienna: IAEA, 2011. - $31 \mathrm{p}$.

26. Table of isotopes CD-ROM. Eight edition. Ver. 1.0, March 1996 / Firestone R. B., Shirley V. S., Chu S. Y. F., Baglin C. M., Zipkin J. - LBNL, Berkeley (USA) and University of California (USA): WileyInterscience, 1996.

27. Jeong $C$. J. Recycling of high burnup spent PWR fuel in CANDU reactors / Jeong C. J., Iqbar., Roh G. H. // American Nuclear Society. International Conference on the New Frontiers of Nuclear Technology: Reactor Physics, Safety, and High-Performance Computing (PHYSOR 2002). Seoul, Korea, October 7-10, 2002.

28. Choi H. Comparison of DUPIC fuel composition heterogenity control methods. KAERI/TR-1370/99 / Choi H., Ko W. I. - Korea Atomic Energy Research Institute, August 1999. - 66 p.

29. Oh W.-Z. Environmental friendliness of back end fuel cycle options. IAEA-SM-357/69 / Oh W.-Z., Song K.-C. - Vienna: IAEA. - 8 p. 
30. Choi H. Burnable Poison Option for DUPIC Fuel. KAERI/ TR-744/96 / Choi H., Gupta H. P. - Korea Atomic Energy Research Institute, August 1996. $-53 \mathrm{p}$.

31. Management of spent fuel from nuclear power reactors. Proceedings of an International conference, Vienna, 19-22 June 2006. Proceedings series. - Vienna: IAEA, 2007. - $506 \mathrm{p}$.

32. Радиационные характеристики облученного ядерного топлива: Справочник / В. М. Колобашкин, П. М. Рубцов, П. А. Ружанский, В. Д. Сидоренко. - М.: Энергоатомиздат, 1983. $384 \mathrm{c.}$

33. Marques J. G. Evolution of nuclear fission reactors: Third generation and beyond // Energy Conservation and Management. 2010. - Vol. 51. - P. 1774-1780

34. Соколова И. Д. Разработка реакторов на быстрых нейтронах // Атомная техника за рубежом. - 2011. - № 1. - С. 3-15.

35. Швыряев Ю. В. Использование вероятностного анализа при обосновании безопасности АЭС-2006, проектируемой для площадки Нововоронежской АЭС / Ю. В. Швыряев, В. Б. Морозов, Г. В. Токмачев, Е. В. Байкова, В. Р. Чулухадзе, М. В. Федулов // Атомная энергия. - 2009. - Т.106, вып. 3. - С. 123-129.

36. Драгунов Ю. Г. Реакторная установка ВВЭР для проекта АЭС-2006 / Ю. Г. Драгунов, С. Б. Рыжов, В. А. Мохов, В. П. Денисов // Тяжелое машиностроение. - 2007. - № 4. - С. 2-4.

37. Бакай $О$. С. Виступ на зборах НАН України // Вісник НАН України. - 2009. - № 7. - С. 24-28.

38. Popov N. ACR-1000: Advanced CANDU Reactor Design for Improved Safety, Economics and Operability /Popov N. // Presentation of AECL manager (ACR Licensing) at the University of Zagreb, Croatia, April 26, 2007. - 38 p.

39. Advanced Fuel Pellet Materials and Fuel Rod Design for Water Cooled Reactors. Proceedings of a Technical Committee Meeting Held in Villigen, 23-26 November 2009. IAEA-TECDOC-1654. - Vienna: IAEA, 2010. - $241 \mathrm{p}$.

40. Written submission from The Society of Energy Professionals In the matter of Ontario Power Generation Inc. Public Hearing. Darlington New Nuclear Power Plant Project. Joint Review Panel, March 21, 2011 // Ontario Power Generation Inc., Canada. - http:// www.ceaa.gc.ca/050/documents/48146/48146E.pdf

41. Thompson G. R. Risks of Operating Candu 6 Nuclear Plants: Gentilly Unit 2 Refurbishment and its Global Implications / Thompson G. R. - Greenpeace: Greenpeace Canada, November 2008. - $66 \mathrm{p}$.

42. Dastur A. R. The use of depleted uranium for the reduction of void reactivity in CANDU reactors / Dastur A. R., Chan P. S. W., Bowslaugh D. // CAN/CNS Conference Summaries. 32nd Annual Conference of Canadian Nuclear Association and 13 ${ }^{\text {th }}$ Annual Conference of Canadian Nuclear Society, Saint John, New Brunswick (Canada), June 7-10, 1992. - Saint John: CAN/CNS, 1992. P. 46-49.

43. Широков С. В. Нестаціонарні процеси в ядерних реакторах: Навч. посібник / С. В. Широков. - К.: ЗАТ «ВїПОЛ», 2002. $-286 \mathrm{c}$.
44. Халимончук В. А. Моделирование Чернобыльской аварии / В. А. Халимончук, А. В. Кучин // Ядерна та радіаційна безпека. $-2011 .-$ Вип. 3(51). - С. 20-28.

45. Report of the U.S. Department of Energy's Team Analyses of the Chernobyl-4 Atomic Energy Station Accident Sequence. Washington: U.S. Department of Energy, November 1986. - 212 p.

46. Howieson J. Q. Chernobyl -A Canadian Technical Perspective. AECL-9334 / Howieson J. Q., Snell V. G. - Atomic Energy of Canada Limited, January 1987. $-98 \mathrm{p}$.

47. Jeong C.-J. Assessment of CANDU-6 Reactivity Devices for DUPIC Fuel. KAERI/TR-1160/98 / Jeong C.-J., Choi H. - Korea Atomic Energy Research Institute, November 1998. - 63 p.

48. Мохов B. A. Обоснование проектов реакторных установок ВВЭР-1000/1200 при работе АЭС в маневренных режимах / Мохов В. А., Подшибякин М. А. // Тр. Всерос. науч.-практ. конф. «Повышение надежности и эффективности эксплуатации электрических станций и энергетических систем», г. Москва (Россия), 13 июня 2010 г. - М.: Изд. дом МЭИ, 2010. - Т. 1. - С. 103-106.

49. EPR reactor: the very high power reactor $(1650 \mathrm{MWe}) / / \mathrm{http}: / /$ www.areva.com/EN/global-offer-419/epr-reactor-one-of-the-mostpowerful-in-the-world.html?xtmc $=$ EPR $\% 20$ Power\&xtcr $=2$

50. Тепловые и атомные электрические станции: учебник для вузов / Л. С. Стерман, В. М. Лавыгин, С. Г. Тишин. - 5-е изд., стер. - М.: Изд. дом МЭИ, 2010. - 464 с.

51. Gerretsen J. Report and Advice on the Ontario Drinking Water Quality Standard for Tritium / Gerretsen J. - Ontario Drinking Water Advisory Council, May 2009. - 143 p.

52. Galeriu D. Risks from tritium exposure at Chernavoda, Romania / Galeriu D. - Bucharest: «Horia Hulubei» National Institute for Research and Development in Physics and Nuclear Engineering, October 2007. $-35 \mathrm{p}$.

53. Норми радіаційної безпеки України (НРБУ-97). - К.: М-во охорони здоров'я України, 1997. - $121 \mathrm{c.}$

54. Andseta S. R. CANDU Reactors and Greenhouse Gas Emissions / Andseta S., Thompson M. J., Jarell J. P., Pendergast D. R. -Canadian Nuclear Association, 2000. - 13 p. 